\title{
TINGKAT PEMAHAMAN KONSEP DAN KEMAMPUAN MENGAJAR MAHASISWA PADA MATA KULIAH KAJIAN DAN PENGEMBANGAN MATEMATIKA SEKOLAH 2
}

\author{
Nur Farida ${ }^{1}$, Nyamik Rahayu Sesanti ${ }^{2}$, Rosita Dwi Ferdiani ${ }^{3}$ \\ 1,2,3 Universitas Kanjuruhan Malang \\ nurfarida@unikama.ac.id ${ }^{1}$,nyamik@unikama.ac.id ${ }^{2}$,rositadf@unikama.ac.id ${ }^{3}$
}

\begin{abstract}
ABSTRAK
Tujuan penelitian ini yaitu untuk mengetahui tingkat kemampuan pemahaman konsep matematika dan kemampuan dalam mengajar mahasiswa pada mata kuliah Kajian dan Pengembangan Matematika Sekolah 2. Proses belajar mengajar yang berkembang di kelas umumnya ditentukan oleh peran guru dan siswa sebagai individu-individu yang terlibat langsung di dalam proses tersebut. Oleh karena itu, kemampuan serta kesiapan dan pemahaman guru akan materi yang akan diajarkan memegang peranan penting dalam keberhasilan proses belajar siswa. Pemahaman konsep merupakan dasar utama dalam pembelajaran matematika. Agar konsepkonsep dan teorema-teorema dapat diaplikasikan ke situasi yang lain, perlu adanya keterampilan menggunakan konsep-konsep dan teorema-teorema tersebut. Oleh karena itu, pembelajaran matematika harus ditekankan ke arah pemahaman konsep. Subyek penelitian ini sebanyak 48 mahasiswa. Proses pengumpulan data pada panelitian ini menggunakan tes, lembar observasi, dan catatan lapangan. Prosedur yang dilakukan untuk menganalisis data pada panelitian ini yaitu (1) mereduksi data, (2) menyajikan data, dan (3) menarik kesimpulan. Berdasarkan hasil pengamatan dan penilaian tes pemahaman konsep yang dilakukan pada dua kelas, dapat diperoleh bahwa sekitar $80 \%$ mahasiswa telah menguasai konsep dengan baik dan benar dalam menyampaikan materi pelajaran, penggunaan model serta media yang tepat, dan mengelola kelas dengan baik. Namun beberapa mahasiswa sekitar 20\% masih kurang dalam hal pemahaman konsepnya.
\end{abstract}

Kata kunci: pemahaman konsep, mahasiswa, Kajian dan Pengembangan Matematika Sekolah 2.

\begin{abstract}
The purpose of this study is to determine the level of ability to understand mathematical concepts and the ability to teach students in Study and Development of School Mathematics 2 subject. Teaching and learning processes that develop in the classroom are generally determined by the role of the teacher and students as individuals who are directly involved in the process the. Therefore, the ability and readiness and understanding of the teacher for the material to be taught
\end{abstract}




\section{Nur Farida, Nyamik Rahayu Sesanti, Rosita Dwi Ferdiani}

play an important role in the success of student learning processes. Understanding concepts is the main basis in learning mathematics. So that concepts and theorems can be applied to other situations, there needs to be skills in using these concepts and theorems. Therefore, learning mathematics must be emphasized towards understanding concepts. The subjects of this study were 48 students. The process of collecting data in this study uses tests, observation sheets, and field notes. The procedures used to analyze the data in this study are (1) reducing data, (2) presenting data, and (3) drawing conclusions. Based on observations and assessment of concept understanding tests conducted in two classes, it can be found that around $80 \%$ of students have mastered the concept properly and correctly in delivering the subject matter, using appropriate models and media, and managing the class well. But some students about $20 \%$ are still lacking in understanding the concept.

Keywords: concept understanding, students, Study and Development of School Mathematics 2.

\section{PENDAHULUAN}

Pendidikan adalah usaha sadar yang bertujuan untuk mengembangkan kualitas manusia sebagai suatu kegiatan yang sadar akan tujuan. Maka dalam pelaksanaanya berada dalam suatu proses yang berkesinambungan dalam setiap jenis dan jenjang pendidikan semuanya berkaitan dalam suatu sistem pendidikan yang integral dan terpadu (Djamarah, 2005).

Proses belajar mengajar yang berkembang di kelas umumnya ditentukan oleh peran guru dan siswa sebagai individu-individu yang terlibat langsung di dalam proses tersebut. Sedangkan prestasi belajar siswa itu sendiri banyak bergantung pada cara guru menyampaikan pelajaran pada siswanya. Oleh karena itu, kemampuan serta kesiapan dan pemahaman guru akan materi yang akan diajarkan memegang peranan penting dalam keberhasilan proses belajar siswa.

Pendidikan matematika merupakan salah satu pondasi dari kemampuan sains dan teknologi. Pemahaman terhadap matematika, dari kemampuan yang bersifat keahlian sampai kepada pemahaman yang bersifat apresiatif akan berhasil mengembangkan kemampuan sains dan teknologi yang cukup tinggi (Buchori, 2001).

Berdasarkan tujuan pembelajaran matematika di atas, maka siswa diharapkan dapat memahami konsep matematika yang akan digunakan, merancang model matematika, memecahkan masalah matematika dan 
menggunakan penalaran dalam menyelesaikannya. Pemahaman konsep merupakan suatu aspek yang sangat penting dalam pembelajaran, karena dengan memahami konsep siswa dapat mengembangkan kemampuannya dalam setiap materi pelajaran. Pemahaman konsep terdiri dari dua kata yaitu pemahaman dan konsep. Menurut Sardiman (2010), pemahaman (understanding) dapat diartikan menguasai sesuatu dengan pikiran. 1) Pemahaman merupakan perangkat standar program pendidikan yang merefleksikan kompetensi sehinggadapat mengantarkan siswa untuk menjadi kompeten dalam berbagai ilmupengetahuan, sedangkan suatu konsep menurut Hamalik (2008) adalah suatu kelas atau kategori stimuli yang memiliki ciri-ciri umum. 2) Jadi, pemahaman konsep adalah menguasai sesuatu dengan pikiran yang mengandung kelas atau kategori stimuli yang memiliki ciriciri umum.

Tujuan yang akan dicapai dalam penelitian ini adalah (1) Mengetahui seberapa besar pemahaman konsep mahasiswa pada mata kuliah Kajian dan Pengembangan Matematika Sekolah 2, dan (2) Mengetahui implikasi tingkat kemampuan mengajar mahasiswa pada mata kuliah kajian dan pengembangan matematika sekolah 2 terhadap hasil belajar.

Kajian dan pengembangan matematika sekolah 2 merupakan salah satu mata kuliah yang ada di Program Studi Pendidikan Matematika. Mata kuliah ini merupakan prasyarat bagi mahasiswa yang akan menempuh PPL atau Magang 3. Materi pokok dalam pembelajaran kejian dan pengembangan matematika sekolah 2 ini mahasiswa diharapkan mampu menerapkan sebagaimana mahasiswa akan mengajar di depan kelas. Namun lebih dari dari untuk mempersiapkan kemampuan mahasiswa untuk menjadi seorang guru, maka hal yang terpenting penanaman pemahman konsep juga sangat diperhatikan pada mata kuliah ini. Materi yang akan dibahas pada mata kuliah ini meliputi materi-materi pelajaran yang ada di SMP dan SMA/SMK, namun dengan kategori materi-materi yang masih tergolong tingkat sedang. Pentingnya pemahaman konsep pada mata kuliah ini karena akan menentukan berhasil atau tidaknya mahasiswa pada waktu melaksanakan kegiatan PPL dan terjun langsung di sekolah sebagi guru. Maka dari itu pada mata kuliah ini mahasiswa dibekali dengan selain keterampilan dasar 
mengajar juga penanaman konsep pada materi pelajaran yang akan diajarkan di tingkat SMP dan SMA/SMK.

Bentuk format penilaian pemahaman konsep yang digunakan untuk mengukur kemampuan matematika mahasiswa diberikan pada Tabel 1.

Tabel 1. Pemberian Skor Pemahaman Konsep Matematika

\begin{tabular}{|c|c|c|c|}
\hline Skor & Pemahaman Soal & Penyelesaian Soal & Menjawab Soal \\
\hline 0 & Tidak ada usaha & $\begin{array}{l}\text { Tidak ada usaha } \\
\text { memahami soal }\end{array}$ & $\begin{array}{l}\text { Tanpa jawab atau } \\
\text { jawaban salah yang } \\
\text { diakibatkan prosedur } \\
\text { penyelesaian tidak tepat }\end{array}$ \\
\hline 1 & $\begin{array}{l}\text { Salah interpretasi soal } \\
\text { secara keseluruhan }\end{array}$ & $\begin{array}{l}\text { Perencanaan penyelesaian } \\
\text { yang tidak sesuai }\end{array}$ & $\begin{array}{l}\text { Salah komputasi, tidak } \\
\text { ada pernyataan jawab dan } \\
\text { pelabelan salah }\end{array}$ \\
\hline 2 & $\begin{array}{l}\text { Salah interpretasi } \\
\text { pada sebagian besar } \\
\text { soal }\end{array}$ & $\begin{array}{l}\text { Sebagian prosedur benar } \\
\text { tetapi masih terdapat } \\
\text { kesalahan }\end{array}$ & Penyelesaian benar \\
\hline 3 & $\begin{array}{l}\text { Salah interpretasi } \\
\text { pada sebagian kecil } \\
\text { soal }\end{array}$ & $\begin{array}{l}\text { Prosedur substansial benar, } \\
\text { tetapi masih terdapat } \\
\text { kesalahan }\end{array}$ & \\
\hline \multirow[t]{2}{*}{4} & $\begin{array}{l}\text { Interpretasi soal benar } \\
\text { seluruhnya }\end{array}$ & $\begin{array}{l}\text { Prosedur penyelesaian } \\
\text { tepat, tanpa kesalahan }\end{array}$ & \\
\hline & Skor Maksimal = 4 & Skor Maksimal = 4 & Skor Maksimal = 2 \\
\hline
\end{tabular}

Indikator yang digunakan untuk mengukur kemampuan mengajar mahasiswa pada mata kuliah Kajian dan Pengembangan Matematika Sekolah 2 diberikan pada Tabel 2.

Tabel 2. Indikator dan Deskripsi Keterlaksanaan Kemampuan Mengajar Mahasiswa

\begin{tabular}{|c|c|}
\hline Indikator & Deskripsi Keterlaksanaan \\
\hline \multirow[t]{5}{*}{ 1. Membuka Pelajaran } & a. Hanya menyampaikan salam pembuka \\
\hline & b. Menyampaikan salam dan tujuan pembelajaran \\
\hline & c. Menyampaikan salam, tujuan pembelajaran dan \\
\hline & d. Menyampaikan salam,tujuan \\
\hline & $\begin{array}{l}\text { pembelajaran,mengaitkan dengan pelajaran } \\
\text { terdahulu,mengenali entry behavior }\end{array}$ \\
\hline \multirow{4}{*}{$\begin{array}{l}\text { 2. Menggunakan } \\
\text { metode mengajar }\end{array}$} & a. Pemilihan metode tidak relevan dengan situasi kelas \\
\hline & $\begin{array}{l}\text { b. Pemilihan metode tepat, namun kurang terampil } \\
\text { menjelaskan }\end{array}$ \\
\hline & $\begin{array}{l}\text { c. Metodenya variatif namun kurang terampil } \\
\text { menjalankan }\end{array}$ \\
\hline & d. Metode variatif dan terampil menjalankan \\
\hline
\end{tabular}




\begin{tabular}{|c|c|}
\hline Indikator & Deskripsi Keterlaksanaan \\
\hline $\begin{array}{l}\text { 3. } \\
\text { penggunakan media } \\
\text { pembelajaran }\end{array}$ & $\begin{array}{l}\text { a. Tidak ada media pembelajaran yang digunakan } \\
\text { b. Ada media pembelajaran namun kurang relevan } \\
\text { c. Media pembelajaran relevan,dan cukup terampil } \\
\text { menggunakannya } \\
\text { d. Media pembelajaran relevan,lengkap, dan terampil } \\
\text { menggunakannya }\end{array}$ \\
\hline 4. Menjelaskan konsep & $\begin{array}{l}\text { a. Penjelasan tidak rinci dan dangkal } \\
\text { b. Penjelasan cukup rinci dan ada contoh } \\
\text { c. Penjelasan cukup rinci,cukup mendalam, dan ada } \\
\text { contoh } \\
\text { d. Penjelasan rinci, mendalam, dan banyak contoh }\end{array}$ \\
\hline $\begin{array}{l}\text { 5. Mengelola } \\
\text { pertanyaan }\end{array}$ & $\begin{array}{l}\text { a. Ada beberapa pertanyaan namun kurang relevan } \\
\text { b. Ada beberapa pertanyaan yang relevan } \\
\text { c. Pertanyaan cukup variatif dan relevan namun kurang } \\
\text { mendalam } \\
\text { d. Pertanyaan variatif, relevan,mendalam, dan } \\
\text { pengelolaannya baik }\end{array}$ \\
\hline $\begin{array}{l}\text { 6. Penguasaan bahan } \\
\text { ajar }\end{array}$ & $\begin{array}{l}\text { a. Guru tidak menguasai bahan ajar } \\
\text { b. Guru kurang menguasai bahan ajar } \\
\text { c. Guru cukup menguasai bahan ajar } \\
\text { d. Guru menguasai bahan ajar dan mampu } \\
\text { mengembangkannya }\end{array}$ \\
\hline $\begin{array}{l}\text { 7. Kemampuan } \\
\text { mengelola kelas }\end{array}$ & $\begin{array}{l}\text { a. Guru tidak menguasai kelas } \\
\text { b. Guru kurang menguasai kelas } \\
\text { c. Guru cukup menguasai kelas } \\
\text { d. Guru menguasai kelas dan mampu mengelola dengan } \\
\text { baik }\end{array}$ \\
\hline 8. Pengelolaan waktu & $\begin{array}{l}\text { a. Penggunaan waktu untuk setiap tahap tidak tepat } \\
\text { b. Penggunaan waktu setiap tahap sebagian kecil tepat } \\
\text { c. Penggunaan waktu setiap tahap sebagian besar tepat } \\
\text { d. Penggunaan waktu setiap tahap sangat tepat }\end{array}$ \\
\hline $\begin{array}{l}\text { 9. Gerak guru dalam } \\
\text { mengajar }\end{array}$ & $\begin{array}{l}\text { a. Gerak guru terbatas dan canggung } \\
\text { b. Gerak guru terbatas namun tidak canggung } \\
\text { c. Gerak guru cukup variatif namun terlihat canggung } \\
\text { d. Gerak guru variatif, lincah, dan tidak canggung }\end{array}$ \\
\hline $\begin{array}{l}\text { 10. Suara guru dalam } \\
\text { mengajar }\end{array}$ & $\begin{array}{l}\text { a. Suara kurang keras dan kurang jelas } \\
\text { b. Suara cukup jelas, namun tempo dan penekanannya } \\
\text { tidak variatif } \\
\text { c. Suara jelas dan variasinya cukup } \\
\text { d. Suara jelas, variatif, dan sesuai situasi }\end{array}$ \\
\hline 11. Arah pandangan mata & $\begin{array}{l}\text { a. Pandangan mata guru tidak terarah ke seluruh kelas } \\
\text { b. Pandangan mata guru ke seluruh kelas namun tidak } \\
\text { merata } \\
\text { c. Pandangan mata guru ke seluruh kelas dan cukup } \\
\text { merata } \\
\text { d. Pandangan mata guru merata ke seluruh kelas dan } \\
\text { tegas }\end{array}$ \\
\hline
\end{tabular}




\begin{tabular}{|c|c|}
\hline Indikator & Deskripsi Keterlaksanaan \\
\hline \multirow{4}{*}{ 12. Pemberian penguatan } & a. Ada penguatan sekedarnya \\
\hline & b. Ada penguatan yang cukup variatif \\
\hline & c. Ada penguatan yang variatif \\
\hline & $\begin{array}{l}\text { d. Ada penguatan yang variatif dan guru terampil } \\
\text { menggunakannya }\end{array}$ \\
\hline \multirow{4}{*}{ 13. Menutup pelajaran } & a. Guru hanya mengucapkan salam penutup \\
\hline & $\begin{array}{l}\text { b. Guru mengucapkan salam penutup dan membantu } \\
\text { merangkum isi pelajaran }\end{array}$ \\
\hline & $\begin{array}{l}\text { c. Guru membantu merangkum isi pembelajaran, } \\
\text { mengarahkan belajar siswa, dan mengucapkan salam } \\
\text { penutup }\end{array}$ \\
\hline & $\begin{array}{l}\text { d. Guru membentu merangkum, mengarhkan belajar } \\
\text { siswa, mengadakan post test, dan mengucapkan salam } \\
\text { penutup }\end{array}$ \\
\hline
\end{tabular}

\section{METODE PENELITIAN}

Penelitian ini menggunakan pendekatan deskriptif kualitatif, yaitu tidak menguji hipotesis secara empiris, melainkan menghasilkan temuan-temuan yang ada selama penelitian berlangsung. Menurut Moleong (2013) mereka yang menggunakan metode kualitatif berusaha masuk dalam dunia konseptual sebagai perancang kegiatan pembelajaran yang akan dilaksanakan pada proses pembelajaran.

Subjek penelitian adalah mahasiswa Universitas Kanjuruhan Malang. Dalam penelitian ini dipilih kelas A dan B angkatan 2014 yang berjumlah 25 mahasiswa. Peneliti bertindak sebagai pengamat tindakan. Sebagai pemberi tindakan penelitian adalah mahasiswa yang akan menerangkan materi pada mata kuliah Kajian dan Pengembangan Matematika Sekolah (KPMS) 2. Peneliti berperan sebagai pengumpul dan penganalisis data serta sebagai pelapor hasil penelitian.

Sesuai dengan pendekatan yang digunakan dalam penelitian ini yaitu pendekatan kualitatif, maka data yang terkumpul dalam penelitian ini dianalisis dengan menggunakan metode analisis data kualitatif. Pada proses pengumpulan data, instrumen yang diperlukan dalam penelitian ini adalah:

1. Tes

Tes yang digunakan berbentuk uraian. Tes ini bertujuan untuk mengetahui kemampuan dan pemahaman siswa, yang berupa postest. Postest digunakan untuk mengetahui kemampuan siswa setelah mendapatkan perlakuan. 
Sedangkan untuk mengetahui pemahaman konsep mahasiswa tes dilakukan pada saat kegiatan proses mengajar berlangsung.

\section{Lembar Observasi}

Lembar observasi merupakan alat untuk mengetahui sikap serta aktivitas siswa dan guru selama proses pembelajaran berlangsung. Data ini dapat bersifat relatif karena dapat dipengaruhi oleh subjektivitas observer.

3. Catatan Lapangan

Catatan lapangan dimaksudkan untuk melengkapi data yang tidak termuat dalam lembar observasi. Catatan ini berkaitan dengan tindakan-tindakan yang dilakukan oleh partisipan selaku pengajar berikut interaksi yang terjadi antara mahasiswa dan pengajar, interaksi antar mahasiswa selama proses pembelajaran.

Prosedur yang dilakukan untuk menganalisis data mengacu pada pendapat Miles dan Huberman (dalam Arikunto, 2010) yaitu (1) mereduksi data, (2) menyajikan data, dan (3) menarik kesimpulan.

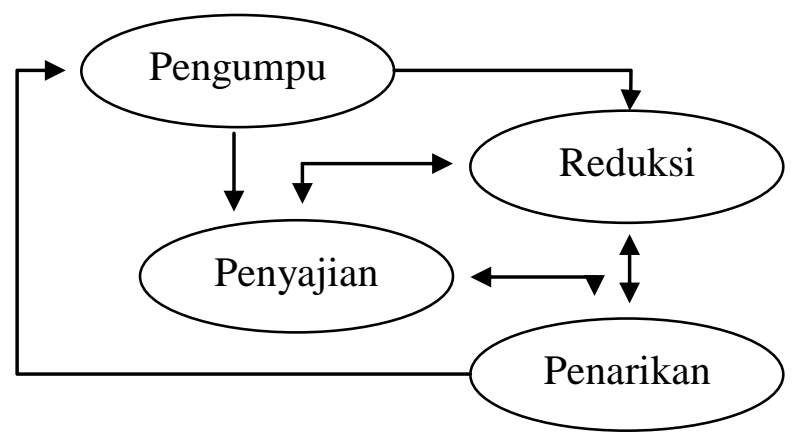

Gambar 1. Teknik Analisis Data

1. Mereduksi data

Mereduksi data adalah proses penyederhanaan data yang diperoleh melalui pengamatan dengan cara memilih data sesuai dengan kebutuhan penelitian. Mereduksi data dilakukan dengan menyeleksi dan menyederhanakan data mentah yang diperoleh dari berbagai sumber yang ada di lapangan. Data yang dimaksud adalah hasil observasi dan tes. 


\section{Nur Farida, Nyamik Rahayu Sesanti, Rosita Dwi Ferdiani}

2. Menyajikan data

Menyajikan data dilakukan untuk memaparkan secara naratif sekumpulan informasi yang telah diperoleh dari hasil reduksi sehingga memberikan kemungkinan penarikan kesimpulan sementara yang berupa indikatorindikator yang berkaitan dengan tindakan pembelajaran yang diberikan yaitu pembelajaranmatematika pada materi pecahan dengan menggunakan media interaktif meliputi hasil observasi dan tes.

3. Menarik kesimpulan

Menarik kesimpulan adalah kegiatan memberikan kesimpulan terhadap hasil penafsiran dan evaluasi, kesimpulan tersebut diverifikasi selama penelitian berlangsung, sedangkan memverifikasi adalah kegiatan menguji kebenaran yang telah disimpulkan. Penyimpulan ini diambil dari data hasil observasi dan tes.

\section{HASIL PENELITIAN DAN PEMBAHASAN}

Berdasarkan hasil pengamatan peneliti terhadap mahasiswa sebagai calon guru ketika mengajar di kelas dalam memahami konsep yang disampaikan pada mata kuliah KPMS 2. Pada praktik mengajar, diperoleh data dari 25 mahasiswa, terdapat 5 orang mahasiswa atau sekitar $20 \%$ yang memperoleh nilai kurang memenuhi dalam kemampuan pemahaman konsep matematika mahasiswa terhadap materi sehingga perlu untuk diantisipasi sebagai perbaikan bagi calon guru. Hasil pengamatan meliputi: 1) beberapa mahasiswa kurang memahami konsep matematika baik itu materi SMP dan SMA, 2) mahasiswa calon guru kurang gigih dalam membimbing siswa menemukan konsep, bahkan cenderung fokus membaca buku sehingga terlihat kurang menguasai konsep materi yang diberikan, 3) mahasiswa calon guru kurang melibatkan siswa dalam proses pembelajaran, 4) mahasiswa masih ragu-ragu ketika menyampaikan materi pelajaran, hal ini terlihat ketika mahasiswa menyampaikan materi, mahasiswa masih terlihat berfikir apa yang hendak disampaikan, dan 5) mahasiswa calon guru masih sering salah ketika menyampaikan materi. Hal tersebut dapat dilihat pada Gambar 2 dan 3 yang menunjukkan kekurang pahaman mahasiswa dalam 
menguasai konsep matematika serta kurang penguasaan dalam mengolah kegiatan belajar.

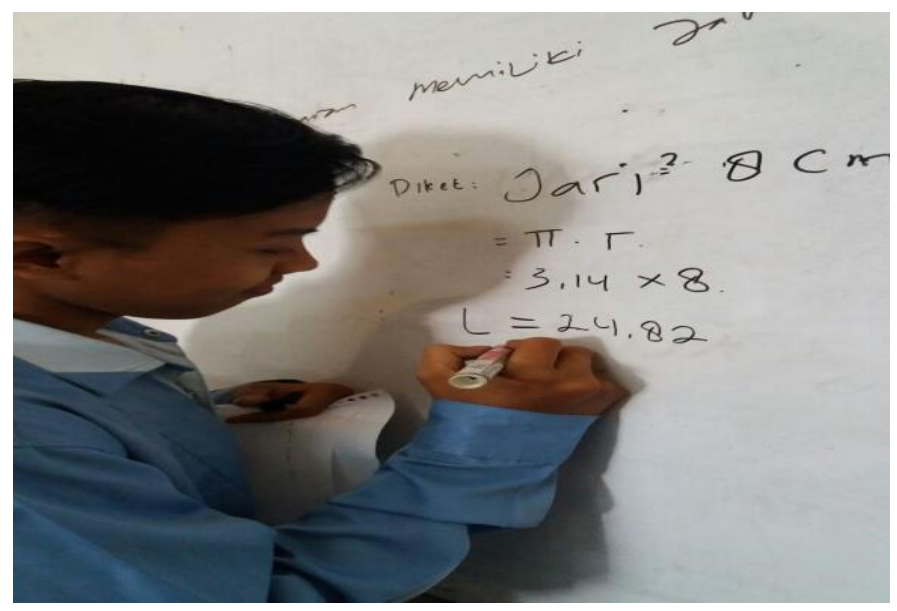

Gambar 2. Salah Satu Mahasiswa Mengerjakan Soal

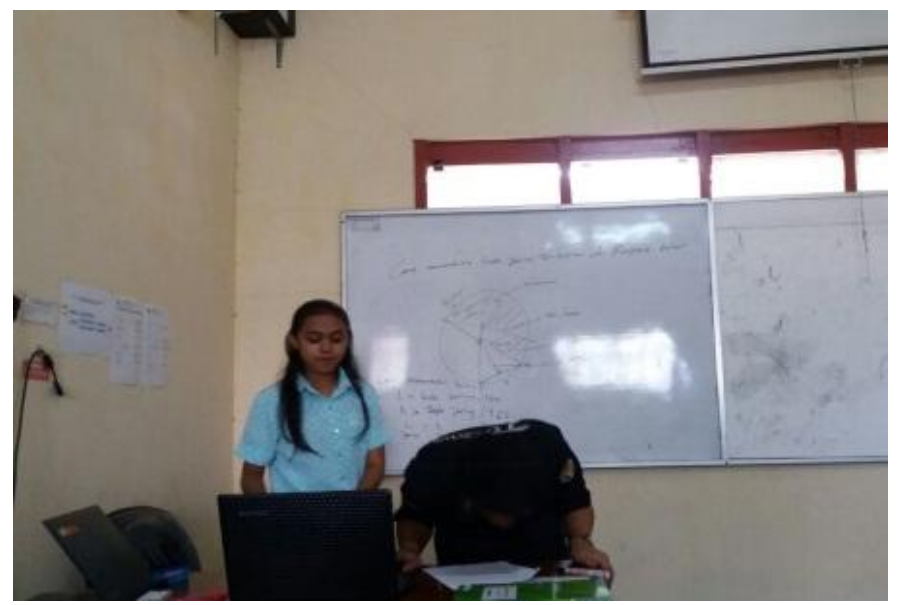

Gambar 3. Mahasiswa Praktik Menjelaskan Tampak Kurang Aktif dalam Kegiatan Belajar Mengajar

Selanjutnya diamati seorang mahasiswa di kelas yang diminta oleh temannya menjawab soal yang diberikan tampak pada Gambar 1. Menurut pengamatan, mahasiswa tersebut secara umum berperilaku sama seperti teman lainnya, namun jika diperhatikan mahasiswa tersebut kurang memperhatikan penjelasan yang disampaikan oleh temannya. Terlihat mahasiswa tersebut salah dalam menjawab soal yang diberikan. Mahasiswa kurang memahami aturan/langkah-langkah dalam menyelesaikan soal serta teknik dalam menulis 


\section{Nur Farida, Nyamik Rahayu Sesanti, Rosita Dwi Ferdiani}

penyelesaiannya. Sepintas terlihat benar penyelesaiannya, namun jika dicermati ternyata tidak sesuai dalam menuliskan solusi.

Untuk menggali seberapa besar pemahaman akan materi yang sudah diajarkan maka diberikan solusi dengan memberi pertanyaan-pertanyaan untuk mengetahuan sejauh mana penguasaan mahasiswa pada pemahaman konsep. Dari pertanyaan-pertanyaan yang diberikan, dapat diketahui besar kemampuan pemahaman konsepakan materi yang dikuasai mahasiswa tersebut. Hal ini terlihat ketika mahasiswa tersebut menjawat dan tingkat pemahaman dan kecepatan dalam menangkap pertanyaan yang diberikan.

Pengamatan tidak hanya dilakukan tiap individu saja, namun juga dilakukan pengamatan dalam tim/kelompok yang menyampaikan materi. Berdasarkan hasil pengamatan didapatkan fakta bahwa beberapa tim/kelompok dalam menyampaikan materi masih banyak membaca buku. Selain itu, isi yang disampaikan di depan kelas kurang mendalam. Mahasiswa masih terlihat malas untuk menjelaskan materi terlihat pada Gambar 3. Kurangnya kemampuan pengelolaan kelas juga terlihat, sehingga kegiatan pembelajaran kurang menarik dan terlihat monoton. Hal ini tentunya menunjukkan kurangnya pemahaman konsep mahasiswa akan materi.

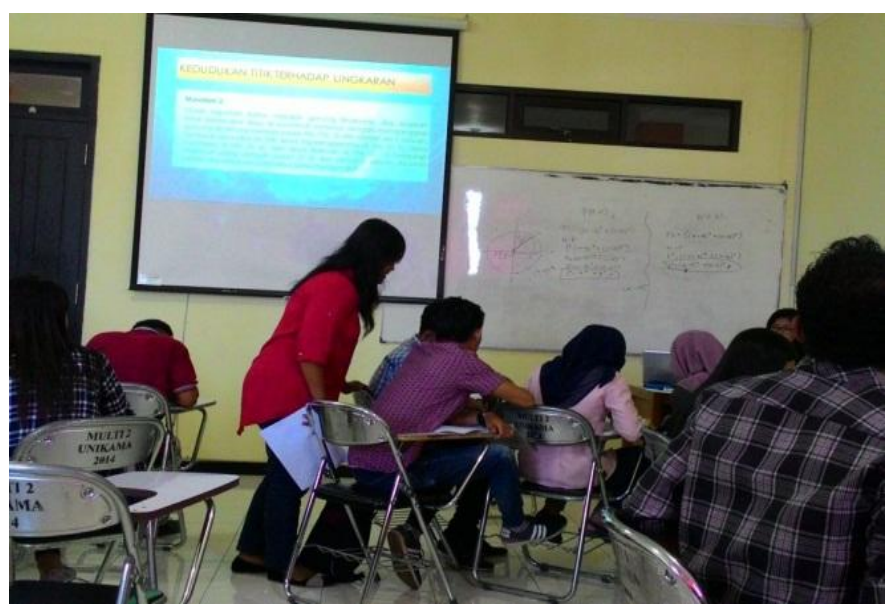

Gambar 4. Salah Satu Mahasiswa Menjelaskan Materi Melalui Media dan Pengelolaan Kelas Melalui Pembelajaran Berkelompok

Selain kelemahan mahasiswa dalam penguasaan konsep dan pengelolaan kelas, terdapat pula kelebihan mahasiswa calon guru yang menunjukkan kemampuan yang baik ketika mengajar di kelas, diantaranya: 1) mahasiswa sudah 


\section{Tingkat Pemahaman Konsep dan Kemampuan Mengajar Mahasiswa pada Mata Kuliah Kajian dan Pengembangan Matematika Sekolah 2}

berupaya menampilkan materi dengan media pembelajaran dengan menarik melalui menayangan powerpoint seperti pada Gambar 4, 2) selain mengemas materi melalui media powerpoint, mahasiswa juga melengkapi ulasan materi yang disampaikan melalui media manipulatif, 3) beberapa mahasiswa sudah menguasai materi dengan baik dan dapat menjelaskan secara terurut, 4) mahasiswa dapat mengembangkan konsep materi yang disajikan serta menghubungkan dengan kehidupan sehari-hari, dan 5) mahasiswa dapat mengaplikasikannya serta membuat contoh soal dan latihan soal yang bervariasi untuk dikerjakan siswa dalam menguji kemampuan pemahaman siswa.

Berdasarkan hasil pengamatan yang dilakukan pada dua kelas, dapat diperoleh kemampuan pemahaman konsep mahasiswa pada materi, yaitu sekitar $80 \%$ mahasiswa sudah dapat mengusai materi dengan baik, dapat mengembangkan konsep tersebut, dan menjelaskan melalui media-media yang menarik dan dapat dipahami oleh siswa. Namun beberapa mahasiswa yaitu $20 \%$ masih kurang dalam hal pemahaman konsep. Sehingga dari hasil tersebut dapat terlihat bahwa kemampuan mahasiswa dalam mengembangkan konsep matematika masih beragam. Sejalan dengan hasil tersebut Sardiman (2010), menyatakan pemahaman dapat diartikan menguasai sesuatu dengan pikiran. Gulo (2008) menyatakan kemampuan-kemampuan yang tergolong dalam pemahaman suatu konsep mulai dari yang terendah sampai yang tertinggi sebagai berikut:

a. Translasi, yaitu kemampuan untuk mengubah simbol tertentu menjadi simbol lain tanpa perubahan makna. Simbol berupa kata-kata (verbal) diubah menjadi gambar, bagan, atau grafik.

b. Interpretasi, yaitu kemampuan untuk menjelaskan makna yangterdapat di dalam simbol, baik simbol verbal maupun yang non-verbal. Dalam kemampuan ini, seseorang dapat menginterpretasikan sesuatu konsep atau prinsip jika ia dapat menjelaskan secara rinci makna atau konsep atau prinsip, atau dapat membandingkan, membedakan, atau mempertentangkan dengan sesuatu yang lain.

c. Ekstrapolasi, yaitu kemampuan untuk melihat kecenderungan, arah, atau kelanjutan dari suatu temuan. Kalau kepada siswa misalnya dihadapi 


\section{Nur Farida, Nyamik Rahayu Sesanti, Rosita Dwi Ferdiani}

rangkaian bilangan $2,3,5,7,11$, maka dengan kemampuan ekstrapolasi mampu menyatakan bilangan pada urutan ke-6, ke-7 dan seterusnya.

\section{SIMPULAN}

Pemahaman konsep merupakan dasar utama dalam pembelajaran matematika. Siswa dikatakan telah memahami konsep apabila ia telah mampu mengabstraksikan sifat yang sama, yang merupakan ciri khas dari konsep yang dipelajari, dan telah mampu membuat generalisasi terhadap konsep tersebut. Berdasarkan hasil pengamatan yang dilakukan pada dua kelas, dapat diperoleh beberapa hasil analisis mengenai kemampuan pemahaman konsep, bahwa mahasiswa telah menguasai konsep dengan baik dan benar dalam menyampaikan materi pelajaran, serta menggunakan model dan media yang tepat, dan mengelola kelas dengan baik.

\section{DAFTAR PUSTAKA}

Abdurrahman. (2007). Metode Penelitian Kualitatif. Bandung: Remaja Rosdakarya.

Arikunto, S. (2010). Prosedur Penelitian (Suatu Pendekatan Praktik). Jakarta: Rineka Cipta.

Buchori. (2001). Notes on Education in Indonesia. Jakarta: Asia Foundation.

De Cecco J. P., \& Crawford W. R. (1997). The Psychology. New Delhi: Prentiee hall of India, Provate Limited.

Djamarah, S. B. (2005). Guru dan Anak Didik dalam Interaksi Edukatif. Jakarta: PT. Rineka Cipta.

Effandi. (2007). Trend Pengajaran dan Pembelajaran Matematik. Kuala Lumpur: Utusan Publications dan Distributors SDN BHD

Gulo, W. (2008). Strategi Belajar Mengajar, Jakarta: Grafindo.

Hamalik, O. (2008). Perencanaan Pengajaran Berdasarkan Pendekatan Sistem. Jakarta: Bumi Aksara.

Hudojo, H. (2005). Pengembangan Kurikulum dan Pembelajaran Matematika. Malang: IKIP.

Moleong, L. (2013). Metode Penelitian Kualitatif. Bandung: Rosdakarya.

Purwanto, N. (2009). Psikologi Pendidikan. Bandung: PT Remaja Rosdakarya.

Sadiman, A. (2010). Interaksi \& Motivasi Belajar Mengajar. Jakarta: Rajawali Pers.

Sugiyono. (2013). Metode Penelitian Kuantitatif, Kualitatif, dan R\&D. Bandung: Alfabeta.

Suwangsih \& Tiurlina. (2006). Metode Penelitian Kualitatif. Bandung: Remaja Rosdakarya. 